Економічні науки: збірник наукових праџь Луцького національного технічного університету. Серія “Регіональна економіка". Випуск 18 (71). Редкол.: відп. ред. д.е.н., професор Л.Л. Ковальська. Луцьк: ІВВ Луиького НТУ, 2021. 278 с.

3. Біліченко В.В., Свершок А.В. Визначення поняття якості пасажирських транспортних послуг та аналіз основних факторів, які на неї впливають. URL: https://ir.lib.vntu.edu.ua/bitstream/handle/123456789/29128/ 9334.pdf?sequence=3\&isAllowed=у (дата звернення 21.09.2021).

4. Офіційний сайт ТОВ «СПЕЦ TEX ЗАХІД» URL: http://spectex.pp.ua/about/

\title{
References
}

1. Popova O.YU., Skybenko H.H. Upravlinnya yakistyu yak element innovatsiynoho rozvytku pidpryyemstva. Ekonomika i orhanizatsiya upravlinnya, 2014. No 3(19) - 4(20). pp. 194-198 [in Ukrainian].

2. Kucheruk H. YU. Ekonomichni metody upravlinnya yakistyu transportnykh posluh. Efektyvna ekonomika. 2012. No 7. URL: http://www.economy.nayka.com.ua/?op=1\&z=1257. (accessed 20.09.2021) [in Ukrainian].

3. Bilichenko V.V., Svershok A.V. Vyznachennya ponyattya yakosti pasazhyrs'kykh transportnykh posluh ta analiz osnovnykh faktoriv, yaki na neyi vplyvayut'. URL: https://ir.lib.vntu.edu.ua/bitstream/handle/123456789/29128/ 9334.pdf?sequence=3\&isAllowed=y (accessed 21.09.2021) [in Ukrainian].

4. Ofitsiynyy sayt TOV "SPETS TEKH ZAKHID" URL: http://spectex.pp.ua/about/ (accessed 23.09.2021) [in Ukrainian].

DOI: https://doi.org/10.36910/2707-6296-2021-18(71)-1

УДК 332.02

Вахновська Н.А., к.е.н., доцент

Луцький національний технічний університет

\section{ПОДАТКОВЕ АДМІНІСТРУВАННЯ: РЕГІОНАЛЬНИЙ АСПЕКТ}

У публікації підлягають розгляду питання сутності та мети податкового адміністрування; визначено основні напрямки посилення інституційної спроможності податкових органів в контексті адміністрування податків; обгрунтовано ефективність адміністрування податків у взаємодії із територіальними органами влади.

Ключові слова: адміністрування податків, податкові органи, органи місцевого самоврядування, інституційна спроможність органів влади. 
Економічні науки: збірник наукових прачь Луиького національного технічного університету. Серія "Регіональна економіка". Випуск 18 (71). Редкол.: відп. ред. д.е.н., професор Л.Л. Ковальська. Луиьк: ІВВ Луиького НТУ, 2021. 278 с.

\section{Vakhnovska N.}

\section{TAX ADMINISTRATION: REGIONAL ASPECT}

The publication considers the essence and purpose of tax administration; the main directions of strengthening the institutional capacity of tax authorities in the context of tax administration are identified; the efficiency of tax administration in cooperation with territorial authorities is substantiated.

Today there is a question of reforming the public financial management system. The defining directions and tasks are: improving the functioning of the tax and customs systems, achieving predictability and balance of fiscal policy in the next 3-5 years, identifying fiscal risks and taking measures to minimize their impact on the budget. Thus, the European course of our state provides for the application of effective mechanisms of tax administration.

The purpose of tax administration is the full implementation of the main functions of taxes - fiscal, distributive and regulatory. The term "tax administration" implies a set of decisions and procedures of regulatory authorities that: 1) determine the institutional structure of tax and customs relations; 2) organize the accounting of objects of taxation and taxpayers; 3) provide service to taxpayers; 4) ensure the organization and control over the payment of taxes.

The state of the country's tax administration is assessed by international organizations in order to increase the transparency of accountability in the areas of public finance management and revenue collection. The activity of the tax service in Ukraine in terms of its functional responsibilities in the direction of tax administration and other tax payments is generally in line with international practice of tax administration.

In Ukraine, the organizational model of the State Tax Service is being built on a functional principle with a management vertical. The article identifies specific measures to improve the efficiency of tax authorities in order to strengthen their institutional capacity. There is also a problem of reforming the tax service in the direction of improving the efficiency of tax administration in cooperation with local authorities, businesses and citizens.

The article stipulates that local governments can have a real impact on the amount of tax revenues to local budgets. To establish taxes and the sizes of their rates within the limits of the current legislation belongs exclusively to the competence of territorial bodies of local government. Accordingly, the timely and complete formation of local budgets' own revenues depends on the effective organization of such works. Therefore, it is important and necessary to give local governments the right to use the tax base and resource-material base in order to determine the economic potential of the region or community. It is also advisable to identify incentives for local governments to establish and collect local taxes. This can be done on the basis of: 1) improving the exchange of information between local authorities and tax authorities, 2) simplifying the system of tax administration in general; 3 ) harmonization of the tax administration system with world standards. 
Економічні науки: збірник наукових прачь Луиького національного технічного університету. Серія “Регіональна економіка". Випуск 18 (71). Редкол.: відп. ред. д.е.н., професор Л.Л. Ковальська. Луиьк: ІВВ Луиького НТУ, 2021. 278 с.

Key words: tax administration, tax authorities, local governments, institutional capacity of authorities.

Вахновская Н.А.

\section{НАЛОГОВОЕ АДМИНИСТРИРОВАНИЕ: РЕГИОНАЛЬНЫЙ АСПЕКТ}

В публикации подлежат рассмотрению вопросы сущности и цели налогового администрирования; определено основные направления усиления институциональной способности налоговых органов в контексте администрирования налогов; обосновано эффективность администрирования налогов во взаимодействии с территориальными органами власти.

Ключевые слова: администрирование налогов, налоговые органы, органы местного самоуправления, институциональная состоятельность органов власти.

Постановка проблеми у загальному вигляді та ії зв'язок 3 важливими науковими та практичними завданнями. Україна нині постає перед масштабними викликами у вигляді пандемії COVID-19 і продовження збройної агресії на сході держави, що потребує додаткових фінансових ресурсів, а $з$ боку державних органів влади прийняття ефективних i результативних рішень в контексті управління публічними фінансами. В останні роки було прийнято ряд надзвичайно важливих фіскальних заходів, які дозволили досягти макроекономічної стабільності та контрольованості соціально-економічних процесів у регіональному i державному вимірі. Проте, забезпечити відтворення і ріст показників соціально-економічного розвитку держави та iі регіонів в середньостроковій перспективі можливо, вживши конкретних заходів по підвищенню ефективності використання бюджетних коштів, проведенню виваженої бюджетно-податкової політики в напрямку формування публічних фінансів, покращення інвестиційноінноваційного клімату, удосконаленню системи податкового адміністрування тощо. На сьогодні гостро постає питання реформування системи управління державними фінансами, в процесі якого визначальними напрямками i завданнями $\epsilon$ : покращення функціонування податкової та митної систем, 
Економічні науки: збірник наукових прачь Луиького національного технічного університету. Серія "Регіональна економіка". Випуск 18 (71). Редкол.: відп. ред. д.е.н., професор Л.Л. Ковальська. Луиьк: ІВВ Луцького НТУ, 2021. 278 с.

забезпечення передбачуваності та збалансованості фіскальної політики в найближчі 3-5 років, завчасне виявлення фіскальних ризиків та вжиття заходів задля уникнення або мінімізації їх впливу на бюджет. Очевидним $\epsilon$ важливість застосування ефективних механізмів податкового адміністрування у реалізації європейського курсу нашої держави.

Аналіз останніх досліджень, у яких започатковано вирішення проблеми. Основа для реформування системи управління державними фінансами в контексті податкового адміністрування викладена у працях відомих вченихекономістів, зокрема О. Бандурки, О.Драган, В. Кміть, А. Крисоватого, К. Проскури, А. Соколовської, І. Цимбалюк, I. Шавло та ін. Проте, питанням впливу податкового адміністрування на соціально-економічні процеси у регіональному вимірі приділено недостатньо уваги та потребують додаткових наукових пошуків.

Цілі статті: визначити заходи з підвищення ефективності діяльності податкових органів та шляхи посилення інституційної спроможності органів місцевого самоврядування у адмініструванні податків.

Виклад основного матеріалу дослідження 3 повним обгрунтуванням отриманих наукових результатів. Реалізація механізму управління податковими відносинами, що орієнтоване на досягнення конкретних результатів відбувається через адміністрування податків та $є$ практичним втіленням управлінсько-розпорядчого процесу, який здійснюється за допомогою певного механізму та має забезпечити раціональну реалізацію моделі фіскального регулювання, запровадженої у державі. Відповідно, податкове адміністрування має на меті повноцінне виконання основних функцій податків - фіскальної та розподільчо-регулюючої [1].

Класично, термін «податкове адміністрування» передбачає сукупність норм і правил, методів, засобів і дій, за допомогою яких спеціально уповноважені органи держави здійснюють управлінську діяльність у податковій сфері, спрямовану на контроль за дотриманням законодавства про 
Економічні науки: збірник наукових праџь Луцького національного технічного університету. Серія "Регіональна економіка". Випуск 18 (71). Редкол.: відп. ред. д.е.н., професор Л.Л. Ковальська. Луиьк: ІВВ Луиького НТУ, 2021. 278 с.

податки та інші податкові платежі, за правильністю їх нарахування i повнотою сплати та притягнення до відповідальності порушників податкового законодавства [2].

Законодавчо, адміністрування податків - це сукупність рішень та процедур контролюючих органів і дій їх посадових осіб, що визначають інституційну структуру податкових та митних відносин, організовують ідентифікацію і облік об'єктів оподаткування та платників податків, забезпечують сервісне обслуговування платників податків, а також організацію та контроль за сплатою податків, зборів, платежів [3].

Очевидним $є$ те, що стан податкового адміністрування країни як члена міжнародної спільноти підлягає оцінці міжнародними інституціями 3 метою підвищення прозорості підзвітності у сферах управління державними фінансами та збирання доходів, а також приведення фіскальних інституцій у відповідність до сучасної міжнародної практики.

За результатами щорічного дослідження Paying Taxes 2020 («Оподаткування 2020»), яке проводить Price Waterhouse Coopers (РwC) спільно зі Світовим банком, Україна опустилася з 54-го на 65-те місце серед 190 країн світу. Україна втратила колишню позицію, оскільки інші країни активніше автоматизують i скорочують час адміністрування податків. Крім того, в Україні збільшилося фіскальне навантаження на бізнес (дані рейтингу PwC) [4]. У середньому українці витрачають на облік 328 годин на рік, що вдвічі більше, ніж у розвинених країнах. А за тривалістю обліку ПДВ наша держава посідає 176 сходинку зі 190 [5]. Індекс України за проведенням додаткових процедур після подачі податкової звітності складає 86, в той час як по країнах Свропи та центральної Азії в середньому - 68 .

Незважаючи на обумовлені недоліки у роботі податкових органів, варто зазначити, що діяльність останных в Україні за ії функціональними обов'язками в напрямку адміністрування податків та інших податкових платежів в цілому відповідає міжнародній практиці податкового адміністрування. Відмінність полягає в якості забезпечення належних умов i значному спрощенні необхідних процедур під час виконання податкового 
Економічні науки: збірник наукових прачь Луиького національного технічного університету. Серія "Регіональна економіка". Випуск 18 (71). Редкол.: відп. ред. д.е.н., професор Л.Л. Ковальська. Луиьк: ІВВ Луцького НТУ, 2021. 278 с.

обов'язку платниками податків, що робить податкову систему України, на думку фахівців, менш ефективною порівняно 3 іншими країнами [1].

Актуальною залишається подальша діджиталізація роботи податкових органів; скорочення часу, який витрачає бізнес на облік і сплату платежів до бюджету, має стати пріоритетним напрямком удосконалення адміністрування податків на регіональному рівні.

3 метою посилення інституційної спроможності податкових органів в Україні вибудовується організаційна модель ДПС за функціональним принципом 3 управлінською вертикаллю. Тому, визначені наступні заходи 3 підвищення ефективності діяльності органів ДПС в даному напрямку:

1) чітка координація діяльності податкової, митної служб і окремих підрозділів правоохоронних органів зі створенням електронної інтегрованої системи відстеження руху товарів;

2) формування оптимальної управлінської моделі податкового адміністрування на підставі комплексного оцінювання законодавчих та організаційних засад iï функціонування в контексті процесів глобалізації;

3) комплексний підхід до розвитку системи управління податковими ризиками;

4) законодавче обгрунтування поняття i затвердження порядку проведення е-аудиту, запровадження української версії податкового аудиторського файлу (SAF-TUA);

5) виокремлення у складі податкових органів окремих підрозділів, що будуть здійснювати адміністрування місцевих податків на основі взаємодії 3 органами місцевого самоврядування, 3 делегуванням останнім частини повноважень 3 адміністрування податків, зборів та обов'язкових платежів;

6) удосконалення механізмів супроводження справ за участю податкових органів;

7) формування інституційної моделі надання податкових експертиз з метою підвищення ефективності та дієвості здійснення податкового контролю (через створення спеціалізованого наукового підрозділу на базі навчального 
Економічні науки: збірник наукових праџь Луцького національного технічного університету. Серія “Регіональна економіка". Випуск 18 (71). Редкол.: відп. ред. д.е.н., професор Л.Л. Ковальська. Луцьк: ІВВ Луцького НТУ, 2021. 278 с.

закладу при Міністерстві фінансів задля здійснення податкових експертиз);

8) створення i запровадження інституту податкової медіації у вітчизняну практику податкового адміністрування 3 дотриманням принципу презумпції правомірності рішень платника податку як альтернативи судовому вирішенню конфліктів, що сприятиме зменшенню кількості оскаржень рішень контролюючих органів, скороченню термінів узгодження податкових зобов'язань та їх сплати, зниженню витрат на сплату судового збору [6].

Реформа децентралізації, розпочата в Україні ще у 2014 році, визначила основні стратегічні орієнтири регіонального $\mathrm{i}$ територіального розвитку. Особливу роль відведено, при цьому, податковій децентралізації, яка передбачає зміцнення та розширення повноважень і прав органів місцевого самоврядування щодо формування територіальних (місцевих) бюджетів за рахунок отриманих податків (зборів та інших обов'язкових платежів) [7]. Проте, однією із визначальних умов економічного зростання країни залишається ефективна робота податкових органів, яка гарантує повноцінне наповнення бюджету, виконання державою своїх функцій і фінансування необхідних реформ. Тому, постає питання реформування органів ДПС в напрямку підвищення ефективності адміністрування податків у взаємодії із територіальними органами влади, бізнесом і громадянами [8].

Залишається неврегульованим питання інформування органів місцевого самоврядування щодо сум нарахованих, сплачених, надмірно сплачених податків до місцевих бюджетів на відповідних територіях. Відсутність інформації в останніх щодо сум накопиченого, списаного чи відстроченого (розстроченого) податкового боргу i грошових зобов'язань платників, сум наданих податкових пільг у розрізі окремих платників призводить до накопичення податкового боргу i, як наслідок, несвоєчасності та неефективності прийняття управлінських рішень органами місцевого самоврядування в контексті формування доходів місцевих бюджетів. 
Економічні науки: збірник наукових праџь Луцького національного технічного університету. Серія “Регіональна економіка". Випуск 18 (71). Редкол.: відп. ред. д.е.н., професор Л.Л. Ковальська. Луиьк: ІВВ Луиького НТУ, 2021. 278 с.

3 позиції Міністерства фінансів України органи місцевої влади наділені правом лише встановлювати пільги по сплаті податків, зборів, платежів, i наявність у них податкової інформації в розрізі платників ніяким чином не впливатиме на суму податкових надходжень до бюджетів та податкового боргу. Однак, 16 січня 2020 року було прийнято Закон України № 466IX «Про внесення змін до Податкового кодексу України щодо вдосконалення адміністрування податків, усунення технічних та логічних неузгодженостей у податковому законодавстві» [9], яким частково вдалось вирішити питання обміну інформацією між органами ДПС та місцевого самоврядування, зокрема, удосконалено порядок подання податковою службою останнім податкової звітності по юридичних особах - платниках податків [10].

Так, органи місцевого самоврядування реально можуть впливати на обсяги надходжень податкових платежів до відповідних місцевих бюджетів, оскільки їх запровадження та встановлення розміру ставок в межах чинного законодавства належить виключно до компетенції таких територіальних органів влади. Відповідно, від ефективної організації комплексу робіт із встановлення, стягнення та мобілізації податків та зборів залежить своєчасне і повне формування значної частини власних доходів місцевих бюджетів. Тому, важливим i необхідним $є$ надання органам місцевого самоврядування права користуватися податковою та ресурсно-матеріальною базами 3 метою визначення економічного потенціалу регіону чи громади, а також інформацією про платників податків.

Висновки. Отже, з метою забезпечення об'єктивності та прозорості планування доходів місцевих бюджетів за джерелами податкових надходжень, а також своєчасного виконання затверджених показників за доходами, територіальним місцевим органам влади необхідно володіти достовірною i повною інформацією не тільки про фактично нараховані та сплачені суми податків і зборів до бюджетів територіальних громад, а й про суми податкового боргу чи надміру сплачених податкових зобов'язань в розрізі платників податків, про відстрочення 
Економічні науки: збірник наукових праџь Луцького національного технічного університету. Серія “Регіональна економіка". Випуск 18 (71). Редкол.: відп. ред. д.е.н., професор Л.Л. Ковальська. Луиьк: ІВВ Луиького НТУ, 2021. 278 с.

(розстрочення) або списання податкової заборгованості і про додаткові джерела надходжень або втрати бюджету. Тому, доцільно визначити стимули для органів місцевого самоврядування 3 метою встановлення та збору місцевих податків, на основі вдосконалення обміну інформацією між ними та податковими органами, спрощення системи адміністрування податків в цілому та іiі узгодження із світовими стандартами.

\section{Список бібліографічного опису}

1. Шавло I.A. Основні напрями вдосконалення системи адміністрування податків в Україні. URL: https://www.ndifp.com/1129/ (дата звернення 18.10.2021)

2. Бандурка О.М., Понікаров В.Д., Попова С.М. Податкове право : навч. посіб. К. : Центр учбової літератури, 2012. 312 с.

3. Податковий кодекс України від 02.12.2010 p. №2755-IV (зі змінами і доповненями). URL: https://zakon.rada.gov.ua/laws/show/ (дата звернення 18.10.2021)

4. Громов Д. Україна втратила 11 позицій у рейтингу Paying Taxes 2020. URL: https://gmk.center/ua/news/ukraina-vtratila-11-pozicij-u-rejtingupaying-taxes-2020/ (дата звернення 20.10.2021)

5. Коментар експертів РwC в Україні щодо результатів спільного зі Світовим банком проекту Paying Taxes URL: https://www.pwc.com/ua/uk/pressroom/2019/paying-taxes-2020.html (дата звернення 20.10.2021)

6. Удосконалення податкової системи України в контексті викликів та загроз, спричинених поширенням COVID-19 : аналітична записка ; за заг. ред. О. Драган, С. Брехова, О. Нагорічної / Мін-во фінансів України, Ун-т ДФС України, Наук.-дослід. ін-т фіскальної політики. Ірпінь, 2020. 96 с.

7. Кміть В.М., Вовчанський Ю.В. Оцінка механізму адміністрування та регулювання місцевих податків та зборів в Україні. Мукачівський державний ун-т. Електронне наукове фахове видання «Економіка і суспільство». 2018. № 15. C. 656-662.

8. Реформування фіскальних органів. URL: https://www.kmu.gov.ua/ diyalnist/reformi/efektivne-vryaduvannya (дата звернення 20.10.2021)

9. Закон України від 16.01.2020 р. №466-IX «Про внесення змін до Податкового кодексу України щодо вдосконалення адміністрування податків, усунення технічних та логічних неузгодженостей у податковому законодавстві». URL: http://search.ligazakon.ua/__doc2.nsf/link1/T200466.html

10. Яка податкова інформація необхідна органам місцевого самоврядування i для яких цілей. URL: https://auc.org.ua/novyna. (дата звернення 22.10.2021) 
Економічні науки: збірник наукових прачь Луиького національного технічного університету. Серія “Регіональна економіка". Випуск 18 (71). Редкол.: відп. ред. д.е.н., професор Л.Л. Ковальська. Луцьк: ІВВ Луиького НТУ, 2021. 278 с.

\section{References}

1. Shavlo I.A. Osnovni napryamy vdoskonalennya systemy administruvannya podatkiv v Ukrayini. Available at: https://www.ndifp.com/1129/ (accessed 18.10.2021) [in Ukrainian]

2. Bandurka O.M., Ponikarov V.D., Popova S.M., eds. Podatkove pravo : navch. posib. Kyiv. Tsentr uchbovoyi literatury, 2012. 312 p. [in Ukrainian]

3. Podatkovyy kodeks Ukrayiny vid 02.12.2010 r. No2755-IV (zi zminamy i dopovnenyamy). Available at: https://zakon.rada.gov.ua/laws/show/2755-17\#Text (accessed 18.10.2021) [in Ukrainian]

4. Hromov D. Ukrayina vtratyla 11 pozytsiy u reytynhu Paying Taxes 2020. Available at: https://gmk.center/ua/news/ukraina-vtratila-11-pozicij-u-rejtingupaying-taxes-2020/ (accessed 20.10.2021) [in Ukrainian]

5. Komentar ekspertiv PwC v Ukrayini shchodo rezul'tativ spil'noho zi Svitovym bankom proektu Paying Taxes Available at: https://www.pwc.com/ua/uk/press-room/2019/paying-taxes-2020.html (accessed 20.10.2021) [in Ukrainian]

6. Udoskonalennya podatkovoyi systemy Ukrayiny v konteksti vyklykiv ta zahroz, sprychynenykh poshyrennyam COVID-19: analitychna zapyska. O. Drahan, C. Brekhova, O. Nahorichnoyi, eds. Min-vo finansiv Ukrayiny, Un-t DFS Ukrayiny, Nauk.-doslid. in-t fiskal'noyi polityky. Irpin', 2020. 96 p. [in Ukrainian]

7. Kmit' V.M., Vovchans'kyy Yu.V. Otsinka mekhanizmu administruvannya ta rehulyuvannya mistsevykh podatkiv ta zboriv $\mathrm{v}$ Ukrayini. Mukachivs'kyy derzhavnyy universytet. Ekonomika i suspil'stvo, 2018, no. 15. [in Ukrainian]

8. Reformuvannya fiskal'nykh orhaniv. Available at: https://www.kmu.gov.ua/ diyalnist/reformi/efektivne-vryaduvannya (accessed 20.10.2021) [in Ukrainian]

9. Zakon Ukrayiny no. 466-IX "Pro vnesennya zmin do Podatkovoho kodeksu Ukrayiny shchodo vdoskonalennya administruvannya podatkiv, usunennya tekhnichnykh ta lohichnykh neuz·hodzhenostey u podatkovomu zakonodavstvi”. Available at: http://search.ligazakon.ua/1_doc2.nsf/link1/T200466.html [in Ukrainian]

10. Yaka podatkova informatsiya neobkhidna orhanam mistsevoho samovryaduvannya i dlya yakykh tsiley. Available at: https://auc.org.ua/novyna. (accessed 22.10.2021) [in Ukrainian]

DOI: https://doi.org/10.36910/2707-6296-2021-18(71)-2 